\title{
Looking Beyond the Climate Change Convention to Attain Global Sustainability Targets
}

\author{
Kalpana S Murari ${ }^{1}$
}

\begin{abstract}
Sustainable Development (SD) is evolving into a major discourse of international law. Very few nations have incorporated the principle within their domestic laws. It is time SD is taken up legally as an aspect of the regulatory domain and implemented globally and nationally. Arctic is one of region that can aid in managing global temperatures if monitored and verified under a mandatory 'monitoring, reporting and verification' (MRV) system. The role of extractive industries that involves gas flaring and increasing shipping activity in the region can lead to increase in Black Carbon (BC) emissions that are considered climate related pollutant. The Arctic is governed by a collection of legally non-binding soft-law multilateral and bilateral agreements and by the United Nations Convention on Law of the Sea (UNCLOS). It is overseen by the Arctic Council, a voluntary group consisting of nations that border the Arctic Ocean with goals of sustainable development and protection of the Arctic environment. The effect of $\mathrm{BC}$ has been thoroughly and scientifically examined and reports are indeed damning. $\mathrm{BC}$ emissions have a direct influence on the sea level rise, a fall out of climate change that is threatening not just a group of people but group of nations that are weak to raise their voice against powerful developed nations. It is time for a binding regulatory and legal regime to curb $\mathrm{BC}$ emissions to prevent future sea level rise. Is the collective conscience of the international community waking up to the crucial role of Arctic in tackling climate change impacts? Can we step up our efforts to actually protect the planet? Can we look beyond the Climate Change Convention for some serious answers? Are we there yet? Yes, IMO just published an investigative report on $\mathrm{BC}$ emissions.
\end{abstract}

Key Words: Arctic Black Carbon, (BC) Verification of Emissions Reduction, MRV, Effects Doctrine, Global Sustainability Targets, Shipping Emissions

\section{Our Planet's tryst with the Arctic}

The idea of Arctic is larger than its geographical contours. As a region in a constant state of flux, the Arctic's climate change manifested in the disappearance of street signs warning on polar bears. The beautiful wilderness of Arctic was populated and heavily polluted even before climate change became a heated topic for debate among scientists and academics. As the Arctic warms and earth's albedo or reflectivity diminishes it leads to more absorption of sunlight, melting of glaciers, sea ice and rise in sea levels. The region is important to climate scientists as it regulates earth's temperature. Scientific modeling suggests that the Arctic may be ice-free by 2030 . The significance of the Arctic lies in the fact that it is nature's vanguard serving as a huge reserve for world's biological resources. The United States Geological Survey claims that the Arctic contains 10 per cent of the world's known petroleum reserves and $25 \%$ of undiscovered reserves.

${ }^{1}$ Lawyer working to contribute to the evolving Environment and Climate Change Laws,

Email id:kalplaw@yahoo.com 
The warming of the Arctic and enlarging ice-free areas points to a huge shift in the ecological landscape of the region and raises numerous geopolitical questions that are accentuated by a demand to declare Arctic as a global common. New navigable routes open up shorter trade routes through the Arctic Ocean providing an impetus to global commerce. The changing landscape places the Arctic under immense pressure from high yielding economic activity. The discourse on Arctic has now shifted to concerns on environmental, economic and military security altering geopolitical equations among Arctic nations. Global shipping activity is likely to increase manifold in the near future leading to higher levels of air pollution including Black Carbon (BC) emissions that are severely harmful to the planet.

The present article discusses the need for a binding framework to regulate Black Carbon (BC) emissions in the Arctic making certain technical and operational measures, including 'slow steaming' as mandatory norms for compliance. A discussion on global multilateral agreement on $\mathrm{BC}$ is on the negotiating table of the international community. There is complete lack of understanding of the solemnity of $\mathrm{BC}$ emissions and its impact on sea level rise while there is clear absence of political will to execute an exclusive treaty for the Arctic. The article offers a discussion on existing norms that regulate air pollution in the region and highlights some of the doctrines and tenets in international law that can ease enforcement of such a treaty, if it were ever to be signed.

\section{Ensuring Arctic Sustainability}

The "Declaration of Principles Governing the Sea-Bed and the Ocean Floor, and the Subsoil Thereof, Beyond the Limits of National Jurisdiction' expressly proclaimed that the seabed and ocean floor, and the subsoil thereof, beyond national jurisdiction (which it referred to as 'The Area') and its resources were the 'common heritage of mankind'. The Area and its resources was not to be subject to appropriation by states or non-state entities, nor could states claim or exercise sovereignty over any part of it. The Area was to be used exclusively for peaceful purposes. Despite the Declaration of principles, industrialized nations have refrained from accepting them as established customary rules or preemptory norms that require absolute adherence. The suggestion to treat the Arctic as a global common subject to international jurisdiction has received little consensus among the Arctic nations. China, South Korea, Japan, and India believe that Arctic should be referred to as the 'common heritage of mankind' for the purpose of promoting sustainable development in the region and further the interests of its indigenous communities.

The voices of smaller nations struggling to survive climate change impacts seems particularly lost in the growing clamor among competing nations to tap the hydrocarbon reserves and exploit natural resources. Invariably, economic interests of nations tend to override consequences of long-term ecological impacts on the planet despite overwhelming scientific evidence.

The Inuit Circumpolar Council, which represents the community of Denmark, Canada, the US and Russia, launched its Circumpolar Inuit Declaration on Arctic Sovereignty on 28 April, 2009, stating "It is our right to freely determine our political status, freely pursue our economic, social, cultural and linguistic development, and freely 
dispose of our natural wealth and resources." This call for greater independence has affected the way the world looks at the region bringing to fore issues of sustainable development and intergenerational equity. In recognizing the inherent rights of these indigenous communities and declaring the region as a global common there are only long term advantages to the planet. It might help to resolve existing military conflicts and border disputes between the Arctic nations and prevent any future confrontations.

\section{Greying of the icecap}

The Institute of Marine Engineering, Science and Technology has proposed a detailed definition of BC to the IMO as

" a strongly light absorbing carbonaceous material emitted as solid particulate matter created through incomplete combustion of carbon-based fuels. ..........BC absorbs solar radiation across all visible wavelengths ..... light absorption varies with the composition, shape, size distribution, and mixing state of the particle."

Black carbon or soot', as it is commonly known, is particulate matter produced during the incomplete combustion of hydrocarbon fuels. BC is a climate-related pollutant with positive feedback loops, where one warming effect can simulate yet another. The short lifespan of $\mathrm{BC}$ could only mean to state that by reducing these emissions we are bound to bring down global temperatures in the quickest possible manner and a sure-footed way to saving Arctic ice to prevent future sea level rise.

There is clinching scientific evidence to state that additional initiatives to limit black carbon can help reduce Arctic warming by about half a degree Celsius by 2050 and deliver real time environmental and economic benefits to the world. Failure to accelerate the momentum of reforms to curb $\mathrm{BC}$ emissions could result in increasing average temperatures around the Arctic by more than 2 degrees Celsius causing irreversible glacier loss, sea ice and permafrost collapse leading to sea level rise.

The World Bank and the International Cryosphere Climate Initiative, submitted a report titled "On Thin Ice: How Cutting Pollution can Slow Warming and Save Lives," which warns that economic costs of failure to address the rapid rise in Arctic could result in crippling global economies, undermining international efforts to alleviate poverty. The report claims that over the next decade, permafrost melting could result in sudden release of stored methane causing extreme weather patterns, frequent storms, floods and severe droughts in some of the developing nations. Prolonged exposure to BC results in untimely deaths. It has been estimated that the mortality rate from $\mathrm{BC}$ emissions is greater than the current annual global death toll from terminal illnesses. The United States and other Arctic nations have tacitly agreed to initiate steps to divest from fossil fuels and heavy fuel oil in the Arctic to address black carbon emissions.

Despite the significance of consolidating efforts to reduce $\mathrm{BC}$ emissions, US Deputy Secretary of State Jim Steinberg indicated that a specific treaty on black carbon would not be negotiated; instead, there would be a "coordinated focus" on taking strong actions domestically. The United Nations Environment Programme (UNEP) announced the creation of a "Climate and Clean Air Coalition to Reduce Short-Lived Climate Pollutants", a voluntary initiative to reduce black carbon. 
Meanwhile, the 2011 SWIPA (Snow, Water, Ice and Permafrost in the Arctic) report claimed that accelerated melt from Arctic glaciers and ice caps, at approximately 40 per cent of the total sea-level rise, was contributing much more than previously envisaged, revising earlier estimates upward to between $0.9-1.6$ meters in sea-level rise by 2100 . The Gothenberg Protocol under the Convention on Long Range Transboundary Air Pollution (CLRTAP) covers BC, as an air pollutant since 2012.

\section{Shipping the Emissions for the Glaciers}

Global shipping fleet emits more than 1.12 billion tons of carbon dioxide, which is more than 3\% of global emissions from ocean-going ships that are unregulated. Shipping and aviation emissions have been consciously excluded from the United Nations Framework for Climate Change Convention (UNFCCC). Marine shipping in the Arctic region may be a small source of $\mathrm{BC}$ emissions that can have significant impact on the climate due to their proximity to Arctic snow and sea ice. Currently, the Arctic nations contribute to about $90 \%$ of shipping activities in the region, influencing future emissions of BC. The Arctic will profit from an altered economic state when new navigable routes for international shipping open up ice-free areas offering a sense of promise for trading partners.

The Arctic Council conducted an Arctic Marine Shipping Assessment in 2009, and thereafter called for mandatory regulations on ship design, construction standards, equipment and technological upgrades. Curbing BC emissions could be the first crucial and legitimate step towards tackling the crisis of climate change. The lagging reforms in Arctic governance have been attributed to nations like Russia that claim lack of reporting inventories for the pollutant.

The Arctic is governed by international customary maritime law of the UNCLOS, other bilateral and multilateral agreements alongside domestic legislations of the eight Arctic States that follow the tenets of Rovaniemi Declaration on the Protection of the Arctic Environment. The Arctic nations committed themselves to a Joint Action Plan of the Arctic Environment Protection Strategy (AEPS) that called for full implementation of measures to control pollutants, establishing an Arctic Monitoring and Assessment Programme Secretariat at Norway.

In April 2015, the Arctic Council adopted a framework to reduce methane and black carbon emissions "resolving to conduct project and sector-based activities, within the Arctic Council and nationally, based on best-available technologies and practices for concrete reductions of black carbon and methane emissions in different sectors of the economy, including also broader programmes that impact the emissions." - Enhanced Black Carbon and Methane Emissions Reductions - An Arctic Council Framework for Action. The initiative is not legally binding on the Arctic States under international law; yet, it is heartening to note that a sector-based approach has been initiated at a time when rapid commercialization of the region is at its threshold.

'International Convention for the Prevention of Pollution from Ships' (MARPOL), an independent international sectoral agreement with a mitigation commitment, and a principal international instrument regulating pollution from international shipping, that presents the possibility of extending its application to long-term emissions reduction by 
harmonizing technology and best practice standards. Under Annex VI of MARPOL, 2005, ships are regulated directly for prevention of air pollution by enforcement of technical standards. In the year 2011, MARPOL parties adopted amendments to Annex VI that would regulate the energy efficiency of ships. In its report to the UNFCCC, the IMO has stated "MARPOL's requirements apply uniformly to ships of different flags, without any differentiation between developed and developing countries. Uniform treatment is justified because of the global nature of the shipping industry as ships competing in a single global market and therefore must be regulated at the global level for any control regime to be effective and to maintain a level playing field for all ships irrespective of flag (nationality) or ownership. In other words, the global character of shipping justifies and requires global regulation that applies universally to all ships." This principle could be the bedrock for a global treaty to regulate $\mathrm{BC}$ emissions.

The International Maritime Organization (IMO) is thrust with the responsibility for safety and security of global shipping and prevention of marine pollution by ships. The Marine Environment Protection Committee (MEPC) is IMO's senior technical body on marine pollution involved in the reduction of GHG emissions from international shipping. The IMO mandates technical and operational measures to be implemented at port, regional and international level, through the adoption of mandatory 'Energy Efficiency Design Index (EEDI) for new ships, and the 'Ship Energy Efficiency Management Plan' (SEEMP) for all ships by the IMO in July 2011. These measures are expected to contribute to reducing maritime GHG emissions. At MEPC 68 in May 2015, a submission from the Marshall Islands, calling for the setting of a quantifiable reduction target for GHG emissions from international shipping was put on hold by the IMO.

Subsequently, on April 22, 2016 at MEPC 69 approved a mandatory system for collecting fuel consumption data from ships. Ships of 5000 gross tonnage or more will have to record and report to their flag State their consumption for every type of fuel they use. The flag State will determine whether the reporting meets requirements, issue a Statement of Compliance to the ship and transfer the data to the IMO Ship Fuel Consumption Database. This policy will be included in the MARPOL, and could possibly enter into force in the year 2018.

The IMO, further, initiated an analytical study pertaining to the control of air related emissions from ships. The study was proffered under the title 'Investigation of appropriate control measures (abatement technologies) to reduce Black Carbon Emissions from International Shipping' and published in 2015. The study claimed that the new data showed lower minimum ice coverage of 3.41 million $\mathrm{km} 2$ as of September 2012 with substantial increase in rate of ice loss. The climate of the Arctic region is known to be warming at almost twice the rate of the rest of the world, half of which is linked to BC. The study reiterated the finding that shipping emissions contributed to BC and therefore Arctic warming and that the warming efficacy of $\mathrm{BC}$ in the Arctic is at least double that of $\mathrm{CO} 2$ as it absorbs incoming and snow-reflected radiation accelerating snow and ice melt.

\section{Sidestepping Climate Intelligence}

The European Union (EU), holds excellent credentials in climate leadership, 
accomplishing maximum compliance of international environmental and pollution norms. As a precursor to the Paris Agreement, the EU, announced its climate policy on cutting down emissions from maritime sector, instating a mandatory norm for 'monitoring, reporting and verification of CO2 emissions' (MRV) system that was adopted on 29 April 2015.

Despite such a clear communiqué from the EU on the importance of reducing maritime emissions, the COP of the United Nations Framework Convention on Climate Change (UNFCCC) managed to circumvent a debate on the topic during negotiations at the Paris summit. The text urging nations to pursue measures to tackle international shipping emissions was withdrawn without a discussion.

"The Paris Agreement does not refer to the Arctic explicitly, but it may nonetheless be the most relevant international treaty to the environmental policies and economic prospects in the region." (The Arctic After Paris I World Policy Institute). The ambitious target to limit global warming to "well below 20 C" was negotiated under the UNFCCC and imposed legal obligations on all countries to report and account for their mitigation actions. Yet, the agreement by itself does not compel parties to subject themselves to a third party scrutiny for 'monitoring, reporting and verification' (MRV) of CO2 emissions.

Any mandatory regulation or policy can succeed when implementation and compliance details are worked out with clarity and transparency that is capable of withstanding due diligence by an independent third party. The principle of 'Verification' has been effective in policies for nuclear nonproliferation working to provide security of the world. The UN, in its Report of the Secretary General, "Verification in all its Aspects, Including the Role of United Nations in the Field of Verification", defines the term 'Verification' as a "process in which data are collected, collated and analyzed in order to make an informed judgment as to whether a party is complying with its obligations." Verification of reports and inventories by an accredited independent third party is crucial to implementing a mandatory MRV in the climate change regime, and it is essential to follow through for incentivizing mitigation programs and funding adaptation programs.

The international community is yet to be convinced that climate change is equally a weapon of mass destruction, and chooses its victims from the underprivileged and economically weak nations whose crusade against sea level rise is deterred by developed nations. Ultimately, the Arctic nations continue to remain unaccountable to those nations that have contributed very little to climate change and it is time to accept a mandate based on equity to protect Small Island Nations and Least Developed Nations (LDCs) from the adverse impacts of Arctic melt.

\section{Slowing down to save the Arctic}

The Clean Shipping Coalition (CSC) had proposed to the IMO on mandatory speed controls of vessels in the shipping sector on the scientific finding that 'slow steaming' as an operational measure could result in fast and efficient reduction of greenhouse gases (GHGs) and Black Carbon emissions. Reduction in speed leads to reduction in $\mathrm{BC}$ emissions when going from higher speeds to medium speeds, as they burn less fuel and emit less air pollutants. It is stated that the 'Ship Energy Efficiency 
Management Plan' (SEEMP) requirement passed by the IMO provides for slow steaming as an operational measure. The speed limits of ships depend on existing market conditions, cost of fuel price and increased competition in supply of container ships. Slow steaming has significant environmental benefits and is widely practiced by many shipping lines. Mandatory slow steaming could offer economic benefits depending on the size of the ships and days of voyage. The need for defined speed levels for each type and size of ship can remove the vagaries that occur due to market fluctuations.

Studies have proved that when defining speed for the purpose of slow steaming, speed through the water is environmentally more relevant than speed over ground. At higher speeds through the water, a ship requires higher engine load that consequently determines a ship's fuel consumption and thus its BC emissions. Monitoring speed through the water can be done by the ship itself under the regulation for submission of fuel consumption data where ships can be compelled to to monitor, document and submit for verification their speed through the water. A ship's speed restriction is dependent on ship size and type that can be monitored based on self-reporting of verifiable data.

Arctic States are geographically equipped to monitor the compliance of any technical standards for ship design and navigational standards when it involves ships making longdistance voyages through different maritime zones. The satellite-based, real-time tracking system that identifies individual ships, with their positioning, direction and speed can help in enforcement of the agreement. Ships sailing through the Arctic waters are expected to keep their transponders operating for tracking purposes. All licensed ships would be monitored for compliance with the equipment and operational standards including slow steaming. Essentially, slow steaming is a viable and feasible option that can have direct impact on BC emissions.

\section{The ABC of Arctic Black Carbon}

The need for an Arctic Black Carbon (ABC) treaty is now long overdue. By providing a universal definition for Black Carbon, IMO can initiate the first step to signing an $\mathrm{ABC}$ treaty that can provide opportunities to operate in the Arctic waters when ships are in compliance with technical and operational standards prescribed under the agreement. The agreement would mandate the formulation of domestic legislations to ensure compliance by ships flying their flag in high seas.

For an international treaty to be successfully implemented, effective domestic legislations under the treaty have to be in place. In the absence of such laws, as in the case of UN arms embargoes, any international effort to bring down global conflicts shall come to a naught. Under Article 41 of the UN Charter, States have a legal obligation to abide by embargoes enacted by the Security Council and a duty to implement measures to ensure that persons within their jurisdiction also comply with the embargoes. However, it is reported that many States have not made the violation of a UN arms embargo a criminal offence under their domestic law. The lack of adequate controls on the activities of arms dealers and transporters of illegal arms at the national level is one of the reasons for the failure in verification of compliance with UN sanctions. Drawing a parallel to climate change regime, domestic laws drafted under international treaties is critical to 
implementing legal obligations endorsed on a global platform.

Enforcement and compliance of globally regulated slow steaming measure can be achieved using flag State obligations and port State rights. Compulsory slow steaming can be imposed by flag states exercising prescriptive jurisdiction over ships flying their flags at high seas. A regulatory norm for slow steaming can be subject to extraterritorial jurisdiction, where port States have the right to impose speed controls on ships flying the flag of non-party States, further, inspect ships entering their ports for compliance of treaty norms and entitled to refuse entry into ports in the absence of such compliance.

\section{Mandating under UNCLOS}

Scholars have analyzed the legal question of "whether the protection of freedom of navigation under UNCLOS can coexist with mandatory slow steaming?" and it has been concluded that in the absence of any judicial authority or treaty norm to state that speed restrictions imposed on ships restrict the freedom of navigation in the high seas, a regime for mandatory slow steaming will not in any way affect the freedom of ships in high seas. If mandatory slow steaming were imposed under the $A B C$ treaty, it would open up a new discourse under international law on regulation of the speed of foreign ships in high seas and grant of rights to a coastal state to enforce compliance by a ship on innocent passage. States do exercise jurisdiction over foreign ships for enforcement of international treaties even where the flag State is not a signatory, suggesting that there is an inherent right to exercise jurisdiction on ships voluntarily entering the ports of a State.

UNCLOS Article 110 provides for exceptions by conferring power to stop, search, and even seize foreign vessels as an exercise of a state's jurisdiction. The use of protective measures is now recognized by UNCLOS Article 221(1), which preserves the right of States to take and enforce measures beyond the territorial sea to protect their coast line or related interests from pollution or threat of pollution following upon a maritime casualty. .... which may reasonably be expected to result in major harmful consequences. Application of this provision can be interpreted to suit the mandatory norm of slow steaming, treating non-compliance as a maritime casualty that could result in BC emissions.

Article 19 of the UNCLOS contains an exhaustive list of activities that may make the passage of a ship within the territorial sea of a coastal state as non-innocent. The most relevant activity to the present context is any 'willful and serious pollution contrary to this convention'. BC emissions are to be treated as serious atmospheric pollution, and violation of a mandatory norm on slow speeding would amount to non-compliance deeming the passage as non-innocent. It is possible for a coastal state to devise domestic legislation under Article 21 of the UNCLOS, and adopt laws applicable to ships on innocent passage through their territorial sea in respect of "preservation of the environment of the coastal State and the prevention, reduction and control of pollution thereof'. Article 25(3) confers on the coastal state a right to suspend innocent passage temporarily in specified areas of the territorial sea if such suspension is essential for the protection of its security.' 
Thus speed restrictions may be prescribed as a pollution reduction measure in relation to vessels undertaking innocent passage. States oppose measures taken by other coastal states when they impede free navigation and hamper the innocent passage of a ship, but when laws for pollution reduction are framed under the auspices of an international treaty, even a non-member would be subject to its prescriptive jurisdiction.

Article 111 of the UNCLOS provides for the hot pursuit of a foreign ship by the coastal State when the ship has violated the laws and regulations of that State. Enforcement and inspection for compliance of regulated slow steaming on high seas would typically raise legal questions on extra-territorial jurisdiction. Enforcing speed restrictions needs to take place at the point where the violation occurs, be it in the high seas or territorial waters. The right of hot pursuit empowers a coastal state to pursue a vessel that has violated international norms not just within its territorial waters but also in the high seas. A mandatory slow steaming regime that offers more environmental benefits than most of the pollution control measures validates the application and exercise of the right to hot pursuit to enforce international pollution control norms in a sensitive region as the Arctic. As a doctrine of maritime extra-territorial jurisdiction, hot pursuit authorizes enforcement actions on the high seas on board vessels that do not fly the flag of the enforcing state.

Under Article 211(3) of the UNCLOS, states are authorized to establish requirements for the prevention, reduction and control of pollution of the marine environment, as a condition for entry into their ports or internal waters. Article 218 of UNCLOS grants power to the port state to undertake investigations and prosecute discharge violations wherever they have taken place beyond national jurisdiction. Complementing these provisions of the UNCLOS, the 1982 Paris Memorandum of Understanding was entered into by maritime authorities of 25 countries, including all Arctic coastal states addressing issues on port state control and means of implementing agreements on maritime safety and protection of the marine environment. Effectively, the Paris Memorandum ensured that foreign merchant ships calling at a port of any of the states complied with the standards set in MARPOL.

\section{Sovereignty and Extra-territoriality}

Jurisdiction is an aspect of sovereignty referring to a state's competence under international law to regulate the conduct of natural and juridical persons. It is by application of prescriptive jurisdiction that a coastal state can prescribe speed restrictions on foreign flagged vessels navigating the Exclusive Economic Zone (EEZ) or high seas and exercise the power to take executive and judicial action against erring parties under enforcement or adjudicative jurisdiction. Extra-territorial jurisdiction may be exercised on an exigency provided under international law for a specific act or behavior deemed as a crime or an offence under a multilateral agreement or treaty.

"The essence of jurisdiction based on the protective principle is that a state may assert its authority over matters which produce a deleterious effect on 'the state', irrespective of where those acts take place or by whom they are committed. National laws based on this principle are said to operate extraterritorially - that is, in respect of acts that take place wholly outside state territory.............. Examples of jurisdiction based on the protective principle were to be found in the national laws of most states... suggesting that the protective principle can be 
regarded as an accepted head of jurisdiction under customary international law. Indeed, it serves a useful purpose in that it permits a state to combat extra-territorial acts, done by aliens, which have an adverse effect on its welfare or security...This is the so-called 'effects doctrine, and it goes beyond the protective principle in that what it is "protected' by legislation is not limited to some public or national interest." - (Textbook on International Law (7th Edn.) Martin Dixon, Oxford University Press.)

The 'effects doctrine' can extend extra-territorial jurisdiction over acts that have deleterious effect on not just the welfare of the enforcing state but universally in the context of climate change. The International Law Commission of the United Nations articulated the following on 'effects doctrine' as:

"may be understood as referring to jurisdiction asserted with regard to the conduct of a foreign national outside the territory of a State that has a substantial effect within that territory."

Similarly, the 'protective principle' may be understood as referring to the jurisdiction that a State may exercise with respect to persons, property or acts abroad that may constitute a threat to the fundamental national interests of a State. The 'universality principle' may be understood as referring to the jurisdiction that a State may exercise with respect to certain crimes under international law in the interest of the international community. Arctic coastal states seek to establish sovereignty over the region to gain unbridled access to the oil and gas reserves of the region paying very little attention to the sustainability of the region and its unambiguous role in global warming.

\section{Conclusion}

The Arctic is clearly a veritable podium to strengthen our fight against climate change and work towards attaining global sustainability targets. The current international legal and regulatory framework is not adequate to address the complex issue of Black Carbon emissions from activities such as Arctic Marine Shipping and gas flaring by extractive industries. There is no dearth of scientific findings on the impact of $\mathrm{BC}$ emissions. Global shipping is one industry that is likely to expand when the Arctic opens up new shipping routes, thereby increasing BC emissions. There is no doubt at this point in time that maritime emissions need to be regulated, especially when they have been excluded under the Paris Agreement. Arctic States act on the notion that they have preemptive rights over the resources in and around the Arctic Ocean. Countries like Russia and China are aggressively pursuing options to tap into its natural resources.

Slow steaming is an operational measure that is already in use and it is time it has been declared as a mandatory norm in global shipping standards. Listing of speed restrictions in a multilateral agreement is one way to prevent vagaries from market fluctuations. International law has enough latitude to implement and enforce pollution norms against erring parties even if they are not signatories to any international treaty. Developed nations and Arctic States need to limit their economic interests in the region using sustainable methods. The clear absence of political will to take appropriate action to preserve the Arctic in the larger interests of smaller nations is certainly disheartening. This is another attempt to force the international community to perceive climate change in the same manner as its victims view it. 


\section{References}

Molenaar, E. J. (2009). Arctic Marine Shipping: Overview of International Legal Framework, Gaps, and Options . Journal of Transnational Law and Policy, 18 (2).

Lefton, R., \& Kelly, C. (2014). Saving The Arctic. Centre for American Progress .

Emmerson, C. (2011). The Future History of The Arctic. London: Vintage Books.

Dixon, M. (2013). Texbook on International Law . London : Oxford University Press .

Koivurova, T., \& Molenaar, E. J. (2009). International Governance and Regulation of the Marine Artic. Oslo: World Wildlife Fund.

Bodansky, D. (2011). Multilateral Climate Efforts Beyond the UNFCCC. Phoenix: Center for Climate and Energy Solutions .

Wood, B. (2006). Strengthening compliance with UN arms embargoes - key challenges for monitoring and verification . London: Amnesty International .

Kolieb, E. H. (2008). Shipping Impacts on Climate: A Source with Solutions. Washington: Oceana.

Carpenter, B. (2009). Warm is the New Cold: Global Warming, Oil, UNCLOS Article 76, And How An Arctic Treaty Might Stop A New Cold War. Environmental Law Review , 215-252.

Molenaar, E. (2009). Arctic Marine Shipping: Overview of The International Legal Framework, Gaps and Options. Journal of Transnational Law and Policy, 289-325.

Ebinger, C. K., \& Zambetakis, E. (2009). The geopolitics of Arctic melt. Journal of Transnational Law and Policy , 18.2, 1215-1236.

Bislaux, A. (2016, February 17). International Institute for Sustainable Development . Retrieved May 30, 2016, from IISD Reporting Services: Emissions from International Transport: http://www.climate-l.iisd.org

Faber , J., Nellissen, D., Hon, G., \& Tsimplis, M. (2012). Regulated Slow Steaming in Maritime Transport . . Delft: CEDELFT.

Duyck, S. (2016, April 27). World Policy Institute . Retrieved May 29, 2016, from World Policy Institute Web Site: www.worldpolicy.org/blog

Williams, M. (2016, May 12). Closing the Arttic Circle: Obama and Nordics can clinch Arctic issues. . Retrieved May 29, 2016, from The Hill web site: www.thehill.com/blogs

Global Ocean Commission. (2013). Modernising Ocean Governance. Somerville: Global Ocean Commission.

The World Bank and International Cryosphere Climate Initiative. (2013). On Thin Ice: How Cutting Pollution Can Slow Warming and Save Lives. Washington: The World Bank.

International Maritime Organisation. (2015). Investigation of appropriate control measures (abatement technologies) to reduce Black Carbon emissions from international shipping. London : IMO.

Lloyd's Register Marine. (2015, May 4). Lloyd's Register Marine/EU/MRV/Guidance. Retrieved May 30, 2016, from Lloyd's Register Marine: www.lr.org

Crawford, J. (2012). Brownlie's Principles of Public International Law. Oxford: Oxford University Press.

O'Neill, J. P. (2010). Verification In An Age of Insecurity. Oxford: Oxford University Press.

Byers, M. (2013). International Law and the Arctic. Cambridge: Cambridge Publications. 